УДК 349.2:3.082.351.741-055.2

DOI https://doi.org/10.32849/2663-5313/2020.10.11

\title{
Наталія Полішко,
}

старший викладач кафедри чивільного права і прочесу

Національної академії внутрішніх справ

\section{ФІЗИЧНА ПІДГОТОВКА ЯК УМОВА РЕАЛІЗАЦІї ТРУДОВОЇ ФУНКЦІї ЖІНКАМИ-ПОЛІЦЕЙСЬКИМИ}

Розглянуто фізичну підготовку жінок-поліцейських як умову реалізації ними трудової функиії, а саме полічейської діяльності, змістом якої є забезпечення охорони прав і свобод людини, протидія злочинності, підтримання публічної безпеки і порядку, та проаналізовано деякі нормативно-правові акти, які регламентують умови прийняття на службу до Начіональної поліиії України осіб жіночої статі.

У статті підкреслюється, що значення всієї правоохоронної системи в Україні у підтриманні правового порядку та забезпеченні безпеки громадянського суспільства є дуже великим. Від ефективної й чітко налагодженої роботи підрозділів Національної поліиії, від взаємодії иих структур з громадськими формуваннями, органами місцевого самоврядування і громадянами багато в чому залежить спокійне й розмірене життя не лише суспільства, але й окремо взятого члена иього суспільства.

Висвітлюючи дану проблематику, автор звертається до широкого спектру наукових розвідок та погоджується з тим, що професійна діяльність співробітників полічії передбачає значні фізичні навантаження, що враховується під час відбору кандидатів на службу у вигляді високих вимог до стану здоров'я, фізичної підготовленості, до здатності переносити тривалі навантаження. Зроблено висновок, що законодавчі вимоги щодо кандидатів на полічейські посади стосуються і жінок, які проходять службу в Національній полічії України, де рівень їхньої фізичної підготовки є складовою частиною проходження ними служби, що має велике значення як під час прийняття їх на службу, так і в прочесі виконання своїх професійних обов'язків.

У статті також підкреслено, що роль фізичної підготовки жінок, які проходять службу в Національній поліиій, $є$ важливою як у досягненні жінками-полічейськими найбільш вагомих результатів у своій професійній діяльності, так і в збереженні життя $і$ здоров'я жінки, в тому числі репродуктивного, під час виконання службових обов'язків.

Сформульовано ряд висновків, спрямованих на оптимізаиію законодавства, що регламентує умови несення служби жінками-полічейськими.

Ключові слова: службова підготовка, фізична підготовка, трудова функція, трудова правосуб'єктність, жінка-поліцейський.

Постановка проблеми. Сьогодні в нашій державі налічується величезна кількість професій та посад, що зумовлює існування різноманітних, а подекуди і спеціальних підходів до трудової правосуб'єктності працівників. Таким чином, для певних професій та для зайняття деяких посад національне законодавство та локальні акти роботодавця встановлюють додаткові вимоги до найманих працівників -кандидатів на посаду. Такі вимоги, як слушно зауважує К. Ю. Мельник, зумовлені особливістю видів трудової діяльності, що в юридичній літературі отримало назву «спеціальна трудова правосуб'єктність». Це можуть бути, вказує автор, вимоги щодо віку, освіти, стану здоров'я, стажу роботи, ділових та моральних якостей, фізичної та психологічної підготовки тощо [1, с. 619].

Не можна не погодитись із С. М. Бортником, який робить обгрунтований висно- вок, що володіння спеціальною трудовою правосуб'єктністю є необхідним для вступу у певні трудові правовідносини. Служба у Національній поліції України є надзвичайно специфічним та відповідальним різновидом трудової діяльності, що визначає і особливе правове становище службовців цього правоохоронного органу та вимоги до їхньої трудової правосуб'єктності [2, с. 57].

Нині вимоги до кандидатів на посади поліцейських встановлено Законом України «Про Національну поліцію» (ст. 49 та ч. 2 ст. 61), якими передбачено, що на службу в поліцію можуть бути прийняті громадяни України віком від 18 років, які мають повну загальну середню освіту, незалежно від раси, кольору шкіри, політичних, релігійних та інших переконань, статі, етнічного та соціального походження, майнового стану, місця проживання, які володіють 
українською мовою [3]. Аналізуючи зазначену норму закону, слід звернути увагу на те, що в ній не згадується ані про особисті ділові та моральні якості кандидатів, ані про рівень їхньої фізичної підготовки. Наголошено лише на тому, що вимоги щодо рівня фізичної підготовки для поліцейських та кандидатів, які вступають на службу в поліції, затверджує Міністерство внутрішніх справ України (ч. 2 ст. 49) [3].

Разом із тим у ст. 17 Закону України «Про міліцію» містилась чітка вказівка на те, що громадянин, який приймається до міліції, повинен «за своїми особистими, діловими та моральними якостями, фізичною підготовкою і станом здоров'я виконувати покладені на міліцію завдання» [4]. До того ж важливою, на наш погляд, була норма про встановлення у разі прийняття на службу в міліцію випробувального строку до одного року. 3 огляду на це, ми підтримуємо пропозицію щодо необхідності доповнення ч. 1 ст. 49 Закону України «Про Національну поліцію» вказівкою на рівень фізичної підготовки кандидата на посаду поліцейського, оскільки це $€$ необхідною передумовою якісної роботи поліцейського, служба якого пов'язана із силовим протиборством із правопорушником. Також вбачається відповідний сенс у тому, що рівень фізичної підготовки слід вважати ключовою вимогою до кандидата на службу до Національної поліції України [2, с. 58].

Аналіз останніх досліджень і публікацій. Особливості фізичної підготовки жінок, які є кандидатами або несуть службу в поліції, висвітлені в роботах багатьох вітчизняних та зарубіжних науковців: Ю. П. Балакіна, В. В. Бондаренка, О. Л. Вєдєнєєвої, А. В. Дадова, В. А. Дідковського, О. А. Жидкової, О. О. Коніка, Б. О. Клименка, О.В.Кузенкова, О. В. Красилова, А. К. Карданова, С. В. Мананнікова, К. Ю. Мельника, Ю. В. Муханова, В. А. Овчіннікова, О. С. Панової, В. С. Якимовича та ін.

Мета статті - розглянути фізичну підготовку жінок-поліцейських як умову реалізації ними трудової функції, а саме поліцейської діяльності, змістом якої $€$ забезпечення охорони прав і свобод людини, протидія злочинності, підтримання публічної безпеки і порядку.

Виклад основного матеріалу. Значення всієї правоохоронної системи в Україні у підтриманні правового порядку та забезпеченні безпеки громадянського суспільства, є дуже великим. Від ефективної й чітко налагодженої роботи підрозділів Національної поліції, від взаємодії цих структур з громадськими формуваннями, органами місцевого самоврядування i громадянами багато в чому залежить спокійне й розмірене життя не лише суспільства, але й окремо взятого члена цього суспільства. Не можна не погодитись із зарубіжними фахівцями, які вказують, що успішність професійної діяльності співробітників органів внутрішніх справ значною мірою визначається їхнім фізичним станом, функціональною та спеціальною фізичною підготовкою, морально-психологічною стійкістю [5, с. 202]. У сенсі наведеного вдалим $є$ і висловлювання А. В. Дадова, який підкреслює, що знання норм закону та вміння застосовувати їх у службовій діяльності $є$ необхідним елементом ефективної служби в системі МВС, однак натепер від співробітника вимагається все більш висока фізична підготовка [6, с. 174]. Розглядаючи питання щодо фізичної підготовки жінки-поліцейського, О. А. Жидкова прямо вказує, що професійна діяльність співробітників поліції передбачає значні фізичні навантаження, що враховується під час відбору кандидатів на службу у вигляді високих вимог до стану здоров'я, фізичної підготовленості, до здатності переносити тривалі навантаження [7, с. 341]. Такі ж вимоги стосуються і жінок, які проходять службу в Національній поліції України, де рівень їхньої фізичної підготовки $є$ складовою частиною проходження ними служби, що має важливе значення як під час прийняття їх на службу, так і в процесі виконання своїх професійних обов'язків.

У спеціальній літературі доволі часто акцентується увага на тому, що співробітники поліції (а це повною мірою стосується і жіночого особового складу), того чи іншого структурного підрозділу, поряд із комплексом знань, умінь та навичок, що дозволяють виконувати свої функціональні обов'язки, повинні: уміти в екстремальних ситуаціях професійної діяльності приймати оптимальні рішення для оперативних та чітких дій; мати навички професійного спілкування 3 різними категоріями громадян; уміти припиняти протиправні дії, в тому числі із застосування фізичної сили, спеціальних засобів, а рівно й із застосуванням вогнепальної зброї [8, c. 158].

Досліджуючи окремі аспекти професійного добору жінок на службу в поліції, О. С. Панова та О. Ю. Плєшивцев вказують, що співробітник-жінка повинна уміти виконувати задачі професійної діяльності не гірше від чоловіка, серед яких затримання правопорушника, звільнення від захватів, захист від ударів озброєного і неозброєного противника, від погрози зброєю, намагання заволодіти зброєю та ін. Перераховані обставини, 
продовжують автори, вимагають від співробітника-жінки добре розвинених фізичних здібностей: сили, швидкості, витримки, координації, формування та удосконалення яких здійснюється в процесі їхньої фізичної підготовки. При цьому необхідно враховувати фізіологічні та психологічні особливості жінок [9, с. 198].

Специфіка службової діяльності підрозділів Національної поліції України дає підстави констатувати, що сучасний працівник повинен володіти не лише знаннями законодавчого блоку, а й розвиненими фізичними якостями та сформованими вміннями і навичками застосування поліцейських заходів примусу. У закладах вищої освіти Міністерства внутрішніх справ України формування такого правоохоронця покладено на спеціальну фізичну підготовку, яка є навчальною дисципліною, у практичних підрозділах - на фізичну підготовку, яка є складовою системи службової підготовки поліцейських [10, с. 6].

Закономірним $є$ те, що такі вміння і навички формуються однаковою мірою і в чоловіків, і у жінок-поліцейських насамперед у процесі професійної підготовки.

Таким чином, необхідно констатувати, що фізична підготовка жінки-поліцейського є одним із головних напрямів службової та професійної підготовки, оскільки в стресових ситуаціях професійної діяльності, пов'язаних із відбиттям нападів, затримкою правопорушників, в тому числі i тих, які чинять активний супротив, що виявляється у невиконанні законних вимог представника поліції під час виконанні його службових обов'язків, перед жінкою-поліцейським стоїть задача затримати порушника, ефективно застосовуючи силові прийоми, спеціальні засоби, а іноді й зброю. При цьому жінка-поліцейський повинна діяти так, щоб не перевищити межі необхідної оборони і заходів, необхідних для правомірного затримання порушника (злочинця).

Слід вказати, що в сучасному суспільстві жінка, яка служить у поліції, далеко не рідкісне явище. Останніми роками кількість жінок, які вступили на службу до поліції, незмінно зростає. I як правильно зазначають дослідники, «це далеко не завжди «кабінетні» посади» [11, с. 410].

Вище зазначалося, що нині жінки несуть службу практично у всіх структурних підрозділах Національної поліції України. Це означає, що вони нарівні з чоловіками виїжджають на місце скоєння злочину, беруть участь у затриманні злочинців, припиняють злочинні посягання на життя, здоров’я людини, власність фізичної чи юридичної особи тощо. Виконання таких завдань зумов- лює необхідність високого рівня фізичної підготовки жінок, які проходять службу в Національній поліції.

Разом із тим необхідно зазначити, що жоден нормативно-правовий документ, що регламентує питання фізичної підготовки співробітників поліції, не містить положень щодо методики та специфіки навчання силових методів, бойових прийомів боротьби саме жінок-поліцейських. Деякі пропозиції щодо врегулювання цього питання трапляються в окремих наукових розвідках. Так, наприклад, А. К. Карданов справедливо підкреслює, що вся система фізичної підготовки жінок-поліцейських повинна будуватися виключно на науковій основі з урахуванням специфіки їхньої професії та професійної діяльності, а також з урахуванням анатомофізіологічних особливостей жіночого організму [8, с. 160].

Щодо самого поняття фізичної підготовки, то вона визначається як плановий та цілеспрямований процес забезпечення готовності співробітників до виконання оперативно-службових занять, умілого та правомірного застосування фізичної сили, бойових прийомів, а також збереження високої працездатності в складних умовах. Метою фізичної підготовки $є$ розвиток та підтримка професійно важливих фізичних якостей на рівні, необхідному для виконання оперативно-службових задач, формування вмінь та навичок ефективного та правомірного застосування фізичної сили, а також підтримка та зміцнення здоров'я, збереження продуктивного рівня загальної працездатності, підвищення стійкості організму до впливу несприятливих факторів службової діяльності [12, с. 139].

Українські фахівці визначають фізичну підготовку як комплекс заходів, спрямований на формування та вдосконалення рухових умінь i навичок, розвиток фізичних якостей та здібностей поліцейського з урахуванням особливостей його професійної діяльності. Відповідно, метою фізичної підготовки поліцейських - збереження здоров'я, творчої та трудової активності, забезпечення належного рівня фізичної готовності та всебічний розвиток фізичних якостей, набуття теоретичних знань, формування спеціальноприкладних та життєво важливих умінь і навичок, необхідних для виконання оперативно-службових завдань $[10$, с. 9,11$]$.

Роль фізичної підготовки жінок, які проходять службу в Національній поліції, є важливою як для досягнення жінками-поліцейськими найбільш вагомих результатів у своїй професійній діяльності, так і для збереження життя і здоров'я жінки, в тому числі репро- 
дуктивного, під час виконання службових обов'язків.

Підводячи деякий підсумок, можна констатувати, що особливості фізичної підготовки жінок-поліцейських зводяться до такого: поповнення та удосконалення індивідуальних навичок, умінь та фізкультурноосвітніх знань, що сприяють засвоєнню вибраної професійно-службової діяльності; інтенсифікація розвитку професійно важливих фізичних та пов'язаних з ними здібностей, забезпечення стійкості та підвищення на цьому підгрунті рівня дієздатності; підвищення рівня адаптаційних можливостей організму щодо несприятливого впливу умов середовища, в яких здійснюється трудова діяльність; сприяння успішному виконанню службових завдань, що реалізуються в загальній системі професійної підготовки кадрів, вихованню моральних, духовних, вольових та інших якостей, які характеризують цілеспрямованих, високоактивних членів суспільства, що створюють його матеріальні і духовні цінності [13, с. 9].

Якщо звернутися до досвіду зарубіжних країн $з$ цього питання, то можна побачити, що йому приділено значну увагу. Зокрема, у Великобританії спеціальна фізична підготовка жінок-поліцейських передбачає різноманітні види боротьби: карате, дзюдо, самбо. Значне місце відведено засвоєнню спортивних єдиноборств, професійній та тактикоспеціальній підготовці. Проблема нападу на співробітників поліції $є$ актуальною і для США, що змушує спеціалістів постійно удосконалювати види, методи фізичної й вогневої підготовки, розробляючи різноманітні програми [14, с. 134].

У Франції з кожним роком збільшується кількість поліцейських, у тому числі й жінок, які отримують під час несення служби різної тяжкості поранень. 3 метою вирішення даної проблеми розробляються методичні посібники, нормативні акти, проводяться тренування, що моделюють різні ситуації оперативно-службової діяльності, посилюються вимоги до фізичної підготовленості кандидатів на службу до поліції, а також періодично переглядаються нормативи фізичної підготовки. Фахівці Німеччини також приділяють значну увагу підвищенню рівня фізичної підготовки працівника поліції [15, с. 342].

Реформування української правоохоронної системи, в тому числі Національної поліції, зумовило необхідність перегляду багатьох аспектів змісту поліцейської діяльності, умов прийому на службу та вимог до кандидатів на посаду поліцейського в цілому та особистого підходу до кожного, хто виявив бажання пов'язати свою професійну діяльність зі служінням суспільству шляхом забезпечення охорони прав і свобод людини, протидії злочинності, підтримання публічної безпеки і порядку зокрема.

Отже, на виконання завдань, покладених на Національну поліцію державою, здійснюється величезних комплекс завдань, змістом яких є постійне удосконалення та підвищення ефективності діяльності поліцейських підрозділів, що значною мірою залежить не лише від рівня їхньої освіти, але і від рівня фізичної підготовленості.

Організація службової підготовки працівників Національної поліції України, складовою частиною якої є фізична підготовка, здійснюється відповідно до наказу МВС України «Про затвердження Положення про організацію службової підготовки працівників Національної поліції України» [16]. Вимоги до рівня фізичної підготовки кандидата на посаду поліцейського містяться у наказі МВС України «Про затвердження Положення з організації перевірки рівня фізичної підготовленості кандидатів до вступу на службу в Національну поліцію України» [17].

Загалом виступаючи за гендерну рівність, зазначимо, що все ж таки очевидним фактом $€$ те, що за певними критеріями рівень фізичної підготовленості та нормативи фізичної підготовки жінок-поліцейських повинні відрізнятися від рівня фізичної підготовки чоловіків-поліцейських. Це не лише визначено відомчими наказами, інструкціями, а й знайшло відображення у відповідних нормах Кодексу законів про працю України.

\section{Висновки.}

Фізична підготовленість жінки $€$ обов'язковою вимогою, яка виступає ключовою умовою під час добору кандидаток на службу в поліцію, а фізична підготовка - частина загальної службової підготовки працівників Національної поліції України.

Фізична підготовка жінки-поліцейського $€$ одним із головних напрямів службової та професійної підготовки, оскільки в стресових ситуаціях професійної діяльності перед жінкою-поліцейським стоїть задача затримати порушника, ефективно застосовуючи силові прийоми, спеціальні засоби, а іноді й зброю.

Рівень фізичної підготовки жінок-поліцейських є тим чинником, який прямо впливає на можливість виконання жінками своєї трудової функції - поліцейської діяльності, яка пов'язана із забезпеченням охорони прав і свобод людини, протидією злочинності, підтриманням публічної безпеки і порядку.

Невиконання обов'язкових нормативів фізичної підготовки жінками-поліцей- 
ськими може свідчити про недостатню ефективність чи навіть неможливість виконання ними своїх безпосередніх службових обов’язків.

Жінка-поліцейський може бути звільненою (тимчасово) від фізичних навантажень у зв'язку 3 особливим станом - вагітністю (та пологами).

\section{Список використаних джерел:}

1. Мельник К. Ю. Загальна та спеціальна трудова правосуб'єктність працівників. Форум права. 2012. № 1. C. 617-624.

2. Бортник С.М. Рівень фізичної підготовки як ключова вимога до кандидатів на службу в Національній поліції України. Підготовка поліиейських в умовах реформування системи МВС України : зб. наук. праць. Харків : ХНУВС, 2018 С. 57-59.

3. Про Національну поліцію : Закон України від 02 липня 2015 року № 580-VIII. Відомості Верховної Ради. 2015. № 40-41. Ст. 379.

4. Про міліцію : Закон УРСР від 20 грудня 1990 року № 565-XII. Відомості Верховної Ради УРСР. 1991. № 4. Ст. 20.

5. Панова О.С. Особенности самостоятельной физической подготовки курсантов женского пола образовательных организаций МВД России. Ученые записки университета имени П.Ф. Лесгафта. 2018. № 5 (159). С. 201-205.

6. Дадов А.В. Состояние и проблемы физической подготовки личного состава органов внутренних дел. Историческая мысль и сочиальное образование. 2016. № 3. Т. 8. Ч. 1. С. 174-177.

7. Жидкова О.А. К вопросу о физической подготовке женщин-полицейских к профессиональной деятельности. Актуальные проблемь огневой, тактико-специальной и профессиональноприкладной физической подготовки : сб. ст. III-й Междунар. науч.-методич. конф. Могилевский институт МВД Республики Беларусь. Могилев, 2016. С. 338-341

8. Карданов А.К. Особенности физической подготовки женщин-полицейских. Историческая мысль и социальное образование. 2016. № 3. Т. 8. Ч. 2. С. 158-161
9. Панова О.С., Плешивцев А.Ю. Психологопедагогические и физиологические особенности физической подготовки женщин - сотрудниц ОВД РФ. Ученые записки университета имени П.Ф. Лесгафта. 2019. № 6 (172). С. 194-198.

10. Дідковський В.А., Бондаренко В.В., Кузенков О.В. Фізична підготовка працівників Національної поліції України : навчальний посібник. Київ: ФОП Кандиба Т.П., 2019. 98 с.

11. Красилов О.В., Мананников С.В., Балакин Ю.П., Веденеева Е.Л. О некоторых особенностях первоначальной профессиональной подготовки женщин - сотрудников ОВД при обучении в образовательных организациях системы МВД России. Вестник экономической безопасности. 2019. № 4. C. 409-412.

12. Коник А.А., Клименко Б.А., Муханов Ю.В. Совершенствование физической подготовки сотрудников МВД России в период профессионального обучения. Проблемы современного педагогического образования. 2018. № 58. C. $139-143$.

13. Карданов А.К. Особенности подготовки сотрудников ОВД при выполнении служебных задач в условиях высокогорий. Наука и бизнес: пути развития. 2013. № 10 (28). С. 7-10.

14. Якимович В.С., Овчинников B.A. Сравнительный анализ методик физической подготовки претендентов на службу в полиции в России и США. Вестник Волгоградской академии МВД России. 2017. № 3 (42). С. 133-136.

15. Панова О.С., Пряхин А.С. Пути и способы совершенствования профессионально-прикладной подготовки сотрудников полиции женского пола. Ученые записки университета имени П.Ф. Лесгафта. 2019. № 11 (177). С. 341-344.

16. Про затвердження Положення про організацію службової підготовки працівників Національної поліції України : наказ МВС України № 50 від 26 січня 2016 року. Офіиійний вісник Украӥни. 2016. № 24. Ст. 861.

17. Про затвердження Положення з організації перевірки рівня фізичної підготовленості кандидатів до вступу на службу в Національну поліцію України : наказ МВС України № 90 від 09 лютого 2016 року. Офічійний вісник України. 2016. № 22. Ст. 864.

Natalia Polishko. Physical training as a condition for the implementation of labor function by women police officers

The physical training of women police officers is considered as a condition for them to perform their labor function, namely police activities, the content of which is to protect human rights and freedoms, combat crime, maintain public safety and order and some regulations governing the conditions of recruitment females to the National Police of Ukraine are analyzed.

The article emphasizes that the importance of the entire law enforcement system in Ukraine in maintaining the legal rule and ensuring the security of civil society is very great. The calm and measured life not only of the society, but also of an individual member of this society largely depends on the effective and wellorganized work of the National Police units, on the interaction of these structures with public formations, local governments, and citizens.

In covering this issue, the author turns to a wide range of scientific research and agrees that the professional activities of police officers involve significant physical activity, which is taken into account when selecting candidates for the service in the form of high demands on health, fitness, ability to withstand prolonged load. 
It is concluded that the legal requirements for candidates for police positions also apply to women serving in the National Police of Ukraine, where the level of their physical training is an integral part of their service, which is important both in their recruitment and in the process of performing their professional duties.

The article also emphasizes that the importance of physical training of women who serve in the National Police and is important both for women police officers to achieve the most significant results in their professional activities and for the preservation of life and health of women, including reproductive, during the performance of official duties.

A number of conclusions have been formulated aimed at optimizing the legislation governing the conditions of service by women police officers.

Key words: professional training, physical training, labor function, labor legal personality, female police officer. 